\title{
Does Monetary Incentives Have Stronger Influence on Workers' Productivity Other Than Any Form of Motivational Incentives?
}

\author{
Adedeji Adebola Daramola \\ Acting Managing Director \\ Owena Energy Limited \\ Ondo State, Nigeria \\ E-mail:adeboladd@gmail.com \\ Lilian Daramola \\ Human Resources Officer \\ Oxpeach Strategy LTD, Lagos, Nigeria \\ E-mail:1iliandaramola884@gmail.com
}

\begin{abstract}
An incentive is a reward given to a person to stimulate his or her actions to a desired direction. It has motivational powers and is widely utilized by small and large organizations to motivate employees. These incentives can either be monetary or nonmonetary. The aim of this study is to find out whether monetary incentives has a stronger influence on workers productiveness other than any form of motivational incentives, using a case study of BORBDA. In order to achieve this, questionnaire was designed, processed and analyzed using Chi-Square. The study revealed that monetary incentives do not exert stronger influence on workers' productivity than any other form of motivational factor. In view of this, money is not the only motivating factor that has stronger influence on workers" productivity, as there are other forms of motivational incentives for employees. The head of organization should look inward for better incentives to motivate their employees without necessarily using monetary incentives.
\end{abstract}

\section{Keywords: Monetary Incentive; Rewards; Motivational Incentives; BORBDA}

\section{Introduction}

\section{I.I Background to Study}

Motivation can be defined as the set of factors that cause people to behave in certain ways (Schwartz, 2006; Daramola, 2019). It is derived from the term motive which is a reason for doing something (Amstrong, 2008), the reason can either be internal (intrinsic) or external (extrinsic) factors (Herzberg et al., 1957). Motivation is among the key concerns of organizations in the modern business environment, as it has been identified to be critical in achieving business goals and objectives. Among the factors that determine employee motivation are satisfaction, recognition, appreciation, inspiration and compensation (Bowen, 2000). Clegg and Birch (2002) argues that the thought of incentive is in itself motivational, in fact most motivation comes from anticipation than the delivery of the incentive itself.

An incentive is a reward given to a person to stimulate his or her actions to a desired direction. It has motivational powers and is widely utilized by small and large organizations to motivate employees. These incentives can either be monetary or non-monetary. Monetary incentives are financial incentives used mostly by employers to motivate employees towards meeting their targets. Money is a symbol of power, status and respect; it plays a crucial role in meeting the social, security and physiological needs of a person. However, money seems not to be a motivator factor when the psychological and security needs are met. This is when it becomes a maintenance factor, as put by Herzberg.

Certain problems of inadequate motivation however do arise as it concerns certain individuals who come into the work situation with differences in expectation, behaviour and outlook. These problems of individual motivation inadequately may be divided into two categories. Firstly, the inability of certain individuals to be motivated may stem from the fact that there is a deficiency in their personality. For such people, the desire to avoid failure may be too strong while paradoxically, the motive to produce positive results may be too weak. This could produce a general resistance to achievement-oriented activity that should naturally be overcome by other extrinsic modes of motivation if there is to be any spur to achievement oriented activity at all.

Secondly, even when the achievement motive is relatively strong, the challenges before the individual worker may be proven to be inadequate or too difficult, whichever of these that apply to the individual worker will usually manifest themselves in different ways such as lack of enthusiasm or premature surrender (Bryans and Crouin, 2005).

In spite of all these apparent attendant problems of motivation, and productivity, every organisation do necessarily seek means of ensuring continuous productivity, which would be geared towards the accomplishment of organisation goals. The organizational 
system under study cannot be said to be different in any way, in terms of producing the result for which it was set up. In all these processes the public organisation and indeed the Benin Owena River Basin Development Authority (BORBDA) has significant impact in Ondo State. The aim of this study is to find out whether monetary incentives has a stronger influence on workers productiveness other than any form of motivational incentives, using a case study of BORBDA.

\section{Literature Review \\ 2.IMonetary Incentives}

When creating a reward program to motivate employees, decision makers and company owners need to understand that the reward or incentive neither guarantees quality output nor loyalty but just a bonus that encourages workers to meet their goals without compromising on quality. Bhasin (2017) explains some of the common examples of monetary incentives;

Piece Rates: This is mostly used in production industries where employees are given a certain amount of money on each produced piece. Piece rates motivate employees to work harder and quickly to produce more pieces as each has a monetary incentive attached to it. However, when issuing piece rates, production supervisors must ensure quality is not compromised.

Pay Raise: These are mostly offered to employees who have worked in a company for a considerable longer period of time. Some companies also give pay rises to employees who have reached a certain level of production or those who have completed the required training programs. Some offer annual salary increment to loyal workers.

Bonuses: Another good form of monetary incentive is issuance of bonuses. These might be bonuses to individuals who have met their sales quotas or even bonuses to teams that have completed their projects in time or have surpassed their production targets. Some companies give yearly Christmas bonuses to long serving employees as a way of rewarding loyalty

Sharing Profits: This is another excellent way of rewarding employees, in which a small profit portion is shared with employees based on their position, duration with the company and input in attaining the overall set goals. Profit sharing is preferred by most companies since it gives employees a sense of belonging and ownership.

Contests: These are mostly offered to sales and production personnel. An additional price or bonus is given to the employee or to a team with the highest production level. Again, Employers can offer cash rewards to employees with best suggestions just to encourage more input in terms of positive ideas that improve on sales, production or performance.

Apart from the above listed forms of monetary incentives, others may include; retirement and education funds, off duty payments and payments to different employee training programs among others.

\subsection{Models Supporting Employee Motivation}

The fields of employee motivation and employee performance are solidly grounded in the researcher of Maslow, Taylor, and Herzberg, to name just a few. The concepts of motivation and performance are constructs within the larger organizational behaviour model. While each of these constructs can be reviewed on their own, employee motivation is linked closely to employee performance. By conducting the search in this manner the resultant articles were specific case studies of employee motivation in various organizations. The resultant case studies looked at a range of topics on both employee motivation and employee performance and how these constructs can be connected.

One particular study looked specifically at $\square$ the followers $\square$ of an organization and what key factors a leader needs to know about the various types of followers. The case studies in this review expand upon the work of Maslow in brief, and Herzberg. In ' Beyond the Fringe' , Simms discusses how various organizations utilize tailored versions of $\square$ non-cash rewards $\square$ as employee incentives. Simms suggests that Herzberg' s view of salary as not being a motivator holds. The ability to hold up an incentive that doesn' t get absorbed by the employee' s monthly bills has a larger effect on employee motivation.

He also suggests it may be more acceptable to boast about a special award or party rather than an employee' s salary raise. Simms then goes on to expand the discussion of non- cash rewards such as flex time, employee of the month, and tailored goal incentives. Simms argues it is important for employers to communicate these benefits to employees because many employees don' $\mathrm{t}$ understand their total compensation package. By communicating the total package, the employer reinforces their commitment to the employees and helps to motivate the employee. This motivation leads to greater employee satisfaction and performance (Simms, 2007).

The case study of the Harrah' s Entertainment sales teams lays out the use of team incentives to increase sales across the various branches of the Harrah' s Entertainment family of products. However, the core to the incentive packages, that Jakobson discusses, is the use of Merchandise Awards. Jakobson states that Merchandise Awards are even more effective than Top Seller Trips. Harrah's also uses simple employee motivation tactics such as recognition at weekly and monthly sales meetings of the top sales teams (Jakobson, 2007).

Whiteling (2007) looks at the cases of Reuters and supermarket giant Sainsbury' s to show how important it is to create a culture where employees become directly involved in suggestions for change. By creating a culture where employee input is valued and utilized, the changes faced by the organization are better understood and receive the support of the employees. This also has the side effect of creating employee motivation to support and accomplish the organizations goals and change efforts (Whiteling, 2007). Silverman utilizes a similar strategy to create a high-performance workforce. Silverman suggests 
keeping employees engaged by working with storytelling. Employers can systematically ask employee' s to tell their story for good or not-so good situations. In this way, an employee/employer relationship can be forged which can help foster mutual support and idea sharing (Silverman, 2006).

Similar to Whiteling, Silverman suggests that the organizations culture needs to be developed around the concept of storytelling. Employees need to feel their stories are being heard, understood, and valued by those requesting the stories. By forging these relationships, the employee feels valued by the employer, supervisor, and organization as a contributor. This value translates into higher work performance and stake within the organization (Silverman, 2006; Whiteling, 2007). Sharbrough' s (2006) study looks at the correlations between leader' s use of Motivating Language (ML) and employee job satisfaction and the perception of a supervisor' s effectiveness. In both cases, there was a statistically significant correlation in this study between a leader' $s$ use of ML and employee job satisfaction and the perception of a supervisor' $s$ effectiveness.

This correlation can be utilized by organizations to measure a leader' s use of ML and determine levels of employee satisfaction as well as determine the perceived effectiveness of a supervisor Kellerman(2007) has expanded the work of Zaleznik, Kelley, and Chaleff to create what he calls a level of engagement to classify the followers of an organization. This employee continuum ranges from $\square$ feeling and doing absolutely nothing $\square$ to $\square$ being passionately committed and deeply involved. $\square$ In this way, a leader can assess their subordinates and tailor a leadership approach to maximize the affect a particular effort will have on employee motivation.

\subsection{Abraham Maslow Theory}

Abraham Maslow (I954) attempted to synthesize a large body of research related to human motivation, prior to Maslow, researchers generally focused separately on such factors as biology, achievement, or power to explain what energizes, directs, and sustains human behavior. Maslow posited a hierarchy of human needs based on two groupings: deficiency needs and growth needs. Within the deficiency needs, each lower need must be met before moving to the next higher level. Once each of these needs has been satisfied, if at some future time a deficiency is detected, the individual will act to remove the deficiency.

Maslow' s theory is difficult to test empirically and has been subject to various interpretations by different writers. Reviews of the need hierarchy model suggest little clear or consistent support for the theory and raise doubts about the validity of the classification of basic human needs. However, it is important to stress that Maslow himself recognizes the limitations of his theory and did not imply that it should command widespread, empirical support. He suggested only that the theory should be considered as a framework for future research and points out: "it is easier to perceive and to criticize the aspects in motivation theory than to remedy them.' Although Maslow did not originally intend that the need hierarchy should necessarily be applied to the work situation, it still remains popular as a theory of motivation at work.

Despite criticisms and doubts about its limitations, the theory has had a significant impact on management approaches to motivation and the design of organizations to meet individual needs. It is a convenient framework for viewing the different needs and expectations that people have, where they are in the hierarchy, and the different motivators that might be applied to people at different levels. The work of Maslow has drawn attention to a number of different motivators and stimulated study and research. The need hierarchy model provides a useful base for the evaluation of motivation at work.

\subsubsection{Frederick Herzbeg Theory of Motivation}

Frederick Herzberg (1923-) had close links with Maslow and believed in a two-factor theory of motivation. He argued that there were certain factors that a business could introduce that would directly motivate employees to work harder (Motivators). However there were also factors that would de-motivate an employee if not present but would not in themselves actually motivate employees to work harder (Hygiene factors). Motivators are more concerned with the actual job itself. For instance how interesting the work is and how much opportunity it gives for extra responsibility, recognition and promotion.

Hygiene factors are factors which ' surround the job' rather than the job itself. For example a worker will only turn up to work if a business has provided a reasonable level of pay and safe working conditions but these factors will not make him work harder at his job once he is there. Importantly Herzberg viewed pay as a hygiene factor which is in direct contrast to Taylor who viewed pay, and piece-rate in particular. Herzberg believed that businesses should motivate employees by adopting a democratic approach to management and by improving the nature and content of the actual job through certain methods. Some of the methods managers could use to achieve this are:

Job enlargement: Workers being given a greater variety of tasks to perform (not necessarily more challenging) which should make the work more interesting.

Job enrichment involves workers being given a wider range of more complexes, interesting and challenging tasks surrounding a complete unit of work. This should give a greater sense of achievement.

life.

Empowerment means delegating more power to employees to make their own decisions over areas of their working 


\subsection{Incentives as Motivational Tools}

In order to keep workers motivated their needs must be addressed as project goals are reached. Satisfying workers' needs can be viewed as distributing incentives when certain objectives are achieved. Employees have needs that they want met and employers have goals that they reach and they can work together as a team to satisfy the wants of both the employees and their employers. Workers who are motivated to help reach the goal of the employer and do so should be recognized with an incentive/reward.

When considering what type of incentives to use there are two types to be aware of, extrinsic and intrinsic.

Extrinsic rewards are external rewards that occur apart from work, such as money and other material things. On the other hand, intrinsic rewards are internal rewards that a person feels when performing a job, so that there is a direct and immediate connection between work and reward. The power of incentives is immense and pervasive, which is all the more reason they require careful management (McKenzie and Lee 1998). Heap (1987) has summarized a list of these advantages and disadvantages associated with financial incentives. Many construction companies have already considered that there can be advantages and disadvantages of developing an incentive program.

A study by Sanders and Thompson (I999) showed that those companies that keep their program simple with the main objective of the program in mind (to benefit the project in reference to cost, schedule, customer service, environment and quality) are also deemed success of any incentive program. Incentives are usually defined as tangible rewards that are given to those who perform at a given level. Such rewards may be available to workers, supervisors, or top managers. Whether the incentive is linked directly to such items as safety, quality or absenteeism, the reward follows successful performance (MaKenzie and Lee, 1998).

Many companies feel that pocket money is to longer a good motivator; others contend that small rewards such as toasters and blenders do not motivate. Many companies therefore offer profit sharing plans; or companies have abandoned monetary rewards and instead offer lavish trips to such places as Europe and some Caribbean islands. Because of the expense, these programs require careful monitoring. Some companies merely reward good producers with an extra day off with pay. Other concerns reward top performers with better working conditions. Since incentive programs aim to increase workers' performance levels, the measure used to decide if a reward has been earned should be carefully set.

The performance level must be attainable or workers won' $t$ try to reach the goal. That fact underscores the usefulness of having workers themselves contribute their ideas about what constitutes a reasonable level of performance. An incentive scheme may also fail if the measure of success ignores quality or safety. An obvious problem exists when an incentive is applied to work that is machine paced. Incentives should b e clearly linked to performance, but not all incentives can be clearly tied to objective criteria. Some incentive rewards are issued on the basis of a subjective assessment by a superior on the merit of particular workers. This method, in particular, may cause conflicts between workers, especially those who do not win rewards (Turkson, 2002).

Every organization is concerned with what should be done to achieve sustained high levels of performance through its workforce. This means giving close attention to how individuals can best be motivated through means such as incentives, rewards, leadership etc. and the organization context within which they carry out the work (Armstrong, 2006). The study of motivation is concerned basically with why people behave in a certain way. In general it can be described as the direction and persistence of action. It is concerned with why people choose a particular course of action in preference to others, and why they continue with chosen action, often over a long period, and in the face of difficulties and problems (Mullins, 2005). Motivation can therefore be said to be at the heart of how innovative and productive things get done within an organization (Bloisi, 2003). It has been established that motivation is concerned with the factors that influence people to behave in certain ways.

\subsection{Effects of Motivation on Productivity}

Productivity in general has been defined in the Cambridge International and Oxford Advance Learner' s dictionaries as the rate at which goods are produced with reference to number of people and amount of materials necessary to produced it. On the other hand, productivity has been defined as the utilization of resources in producing a product or services (Gaissey, I993). It has further been defined as the ratio of the output (good and services) and input (Labour, capital or management). The definition of productivity is utilized by economists at the industrial level to determine the economy' s health, trends and growth rate whiles at the project level, it applies to areas of planning, cost estimating, accounting and cost control (Mojahed, 2005).

Several factors affect labour productivity and prominent among them is the basic education for any effective labour force. In addition to the above is the diet of the labour force and social overhead such as transportation and sanitation (Heizer and Render, 1999). Furthermore, motivation, team building, training and job security have a significant bearing on the labour productivity. Coupled with the afore-stated factors, labour productivity cannot be achieved without maintaining and enhancing the skills of labour and human resource strategies. Better utilized labour with stronger commitment and working on safe jobs also contribute to affect labour productivity (Wiredu, I989). 


\subsection{Effects of Motivation on Performance}

The performance of employees will make or break a company; this is why it is important to find a variety of methods of motivating employees. $\square$ Motivation is the willingness to do something, $\square$ wrote Stephen Robbins and David A. DeCenzo in their book $\square$ Supervision Today $\square \square$ It is conditioned by this action's ability to satisfy some need for the individual. $\square$ The most obvious form of motivation for an employee is money; however, there are other motivating factors that must be considered. Every employee within a company is different and, therefore, is motivated to perform well for different reasons.

Due to the differences within an organization, it is important for a manager to get to know her employees and understand what motivates their performance. $\square$ If you're going to be successful in motivating people, you have to begin by accepting and trying to understand individual differences, $\square$ Robbins and DeCenzo report in their book $\square$ Supervision Today $\square$ Money is the most important motivator for employee performance but it is important for companies to find other ways to motivate. This involves getting to know their employees and what drives them, then making sure managers utilize appropriate motivational techniques with each employee. When appropriate motivation techniques are used, employee performance will improve.

\section{Methodology \\ 3.I Research Design}

A cross section of the staff of BORBDA comprising of 45 subjects drawn from every class and cadre of the organization was sampled. For the purpose of this study, the workers were divided into three major groups namely: the contract staff; the permanent staff officers; and the management staff officers. From analyses, 9\% are management staff, 55.5\% are permanent staff, and the remaining $35.5 \%$ are contract staff. Information was gathered from the population. Questionnaire was used for collecting responses from the subject selected for the study. A total of 45 respondents completed and returned the questionnaires. They all filled and returned questionnaires for analytical purposes.

\subsection{Data Analysis Technique}

Chi-Square test was employed to achieve the analysis. The Chi-Square distribution is a theoretical or mathematical distribution which has wide applicability in statistical analysis. The term 'Chi Square' (pronounced with a hard 'ch') is used because the Greek letter $\chi$ is used to define this distribution. It can be seen that the elements on which this distribution is based are squared, so that the symbol $\chi 2$ is used to denote the distribution (Adeniran, 2018).

The Chi Square statistic is commonly used for testing relationships between categorical variables. The null hypothesis of the Chi Square test is that no relationship exists with the categorical variables in the population; they are independent. Also, it is commonly used to evaluate tests of independence when using a cross tabulation (also known as a bivariate table). Cross tabulation presents the distributions of two categorical variables simultaneously, with the intersections of the categories of the variables appearing in the cells of the table. The Test of independence assesses whether an association exists between the two variables by comparing the observed pattern of responses in the cells to the pattern that would be expected if variables were truly independent of each other (Stephanie, 2018).

In the same vein, $\chi 2$ statistic appears quite different from the other statistics because it can be used for achieving the goodness of fit test and the test of independence. For both of these tests, the data obtained from the sample are referred to as the observed numbers of cases. These are the frequencies of occurrence for each category into which the data have been grouped. In the Chi-Square tests, the null hypothesis makes a statement concerning how many cases are to be expected in each category if this hypothesis is correct. The Chi Square test is based on the difference between the observed and the expected values for each category.

\subsection{Issues regarding Chi Square test}

There are a number of important considerations when using the Chi Square statistic to evaluate a cross tabulation.

I. Chi Square value is extremely sensitive to sample size, when the sample size is too large (approximately 500), almost any small difference will appear statistically significant;

2. It is sensitive to the distribution within the cells and the statistical software tool gives warning message if cells have fewer than five (5) cases. This can be addressed by using categorical variables with a limited number of categories (e.g., by combining categories if necessary to produce a smaller table) (Adeniran, 2018).

In order to test the association between variables, Chi Square tests are used. Chi Square are suitable for nominal type of data (i.e., data that are put into classes: e.g. gender (male, female).type of job (skilled, unskilled, semi skilled) to determine whether they are associated. Nominal data as the word connotes are data that the researcher nominate values to when coding. A Chi Square is said to be significant if there is an association between two variables, and non significant if there is not an association.

As put by Adeniran (2018), Chi Square is said to be useful in a parametric test if the population is small. This is so because a small population requires no statistical estimation for sample size, hence it is needed for significance testing. But it cannot be suitable for parametric test if the population is large. This is so because in order to have an accurate sample size 
estimated from the population such that the population will be adequately represented in the sample; there is need for random sampling technique which is probability sampling. Hence, probability sampling cannot work for Chi Square but non-probability sampling. It measures the association between two variables, or indicates whether the variables are related (Stephaine, 2018; Adeniran, 2018).

\subsection{Study Area}

The Benin Owena River Basin Development Authority (BORBD) together with other Basins in Nigeria was established through the decree that charged them to enhance:

i. Increase in production of food and other raw materials to meet the country's growing population and expanding industries and to attain self-sufficiency in food production.

ii. The expansion of employment opportunities at the rural levels and the need to develop underground water domestic use (FRN,Gazette, I976; Akindele and Adebo, 2004).

In 1976 the Obasanjo regime promulgated the River Basin and Development authorities Decree, creating eleven Basin Authorities distributed all over the country. According to the provisions of Decree, the eleven bodies corporations are:

a) The Sokoto $\square$ Rima River Basin Development Authority;

b) The Hadejia Jama' re River Basin Development Authority;

c) The Chad Basin Development Authority;

d) The Upper Benue River Basin Development Authority;

e) The Lower Benue River Basin Development Authority;

f) The Cross River Basin Development Authority;

g) The Anambra River Basin Development Authority;

h) The River Niger Basin Development Authority;

i) The Ogun-Osun River Basin Development Authority;

j) Benin-Owena River Basin Development Authority;

k) The Niger Delta Basin Development Authority; (RBDA Decree 87, 1979; Akindele and Adebo, 2004).

The River Basin Authorities were charged with the following functions:

a) To undertake comprehensive development of both surface and under ground water resources for multi-purpose use;

b) To provide water from reservoirs and lakes under the control of the Authority for irrigation purposes to farmers and recognized association as well as for urban water supply Authority concerned;

c) The control of pollution in rivers, lakes, lagoons, and creeks in Authority's area in accordance with nationally laid standards;

d) To resettle persons affected by the works and schemes specified under special resettlement schemes;

e) To develop fishes and improve navigation on the rivers, lakes, reservoirs, lagoons and creeks in the authority' s area;

f) To undertake the mechanical clearing and cultivation of land for the production of crops and livestock etc.

g) To undertake large-scale multiplication of improved seeds, live stock and tree seedlings for distribution to farmers and for afforestation schemes;

h) To process crops, livestock products and fish produced by farmers in the authority' s area in partnership with state agencies and any other person;

i) To assist the state and local governments in the implementation of rural development works (construction of small dams, provision of power for rural electrification schemes, establishment of grazing reserves, training of staff) in the Authority's areas (RBDA Decree 87, 1979; Akindele and Adebo, 2004).

In 1984 under the Buhari regime the eleven River Basin Authorities metamorphosed into eighteen Authorities and were redesignated as $\square$ River Basin and Rural Development Authorities (OBRDAS) (FFSDSRP) with one serving the purpose of each state and one for Ogun and Lagos State combined. It was as a result of this metamorphosis that ORBRDA gained autonomy for independent existence in 1984 when it was excised from the old Benin-Owena River Basin and Development Authority (BORBDA) to cater exclusively for Ondo State (ORBRDA, 1987; Akindele and Adebo, 2004; Daramola, 2019).

\section{Discussions of Findings}

For the purpose of achieving the Monetary incentives and rewards exert a stronger influence on workers than any other form of motivational incentives. The Chi-Square $\left(\mathrm{X}^{2}\right)$ analytical method was employed. The following questions were considered. Fat salaries are the best tools with which to motivate workers; and only monetary rewards can bring out the best in workers.

The analysis revealed that the calculated value of $\mathrm{X}^{2}$ (20.7) exceeds the Table value of $\mathrm{X}^{2}(9.49)$, hence the null hypothesis will be rejected and the alternative hypothesis will be accepted. As such, it will be concluded that monetary incentives and rewards does not exert stronger influence on workers' productivity than any other form of motivational factor. In practice and the basic principle of practical management merit pay has been contended that it does not motivate, it could reinforce high performance, extinguish low performance, increase instrumentalities, safety needs, achieve equity and so forth. The reason it does 
not work has to do with implementation and the manner of practice that violate the principle. Most often, performance measures are not valid or accurate. The budget is usually small without much flexibility. Directors are reluctant to give small raises that are insulting or lower than the cost of living and they don' $t$ want to make enemies or be accused of favouring their friends.

\section{Conclusion and Recommendation}

From the study finding, it was therefore concluded that monetary incentives and rewards does not exert stronger influence on workers" productivity than any other form of motivational factor. In view of this, money is not the only motivator factor that has stronger influence on workers" productivity, as there are other forms of motivational incentives for employees. This could justify the perception of Herzberg that money is a maintenance factor and not the only motivator factor when the psychological and security needs are met.

It is prudent to affirm that the reward system or incentives of an organization should be a well thought out plan that is all inclusive and satisfactory. Employees' performance should be monitored and objectively measured against the set goals after which a direct link should be created between the actions of employees and the eventual reward. The head of organization should look inward for better incentives to motivate their employees without necessarily using monetary incentives.

\section{References}

Adeniran, A. O. (2018). Establishing Chi Square as a Non-Parametric Test in Descriptive Statistics. Science \& Technology, 4, I06-II3.

Akindele, S. T., and Adebo, A. (2004). The Political Economy of River Basin and Rural Development Authority in Nigeria: A Retrospective Case Study of Owena-River Basin and Rural Development Authority (ORBRDA).

Akintoye, I. R. (2000). The Place of Financial Management in Personal Psychology. University of Ibadan, Nigeria.

Armstrong, M. (2006). A Hand Book of Human Resource Management Practice. $7^{\text {th }}$ Edition. Kogan Page Limited London NI 9 JN, UK.

Banjoko, S. A. (1996). Human Resource Management. Saban Publishers, Lagos

Bateman, T. S., and Scott, A. S. (I999). Management Building Competitive Advantage. $4^{\text {th }}$ Edition, The McGraw-Hill Companies, Inc.

Bhasin, H. (2017). What are Monetary Incentives? Advantages and Disadvantages of Monetary Incentives. Retrieved from https://www.marketing91.com/monetary-incentives/

Bloisi, W. (2003). Management and Organisational Behaviour. NI, United Kingdom.

Bryans, P. and Cronin, T. P. (2005). Organisation Theory, Facts on File Inc.

Daramola, A. A. (2019). Relationship between Employee Compensation and Productivity: A Case Study of Benin Owena River Basin Development Authority. International Journal of Business and Management Future, 3(2), 22-25.

Federal Republic of Nigeria Official Gazettee Decree 25 of $16^{\text {th }}$ June 1976 Federal Ministry of Information, Lagos (I976).

Festinger, L. (1958). The Motivating Effects of Cognisance Dissnance in G. Lindzey (Ed). Assessment of Human Motives, New York Holt, 1958

Gantt, H. L. (1913). Work, Wages, and Profits. New York: Engineering Magazine Company

Graham, H. T. (1980). Human Resources Management. $3^{\text {rd }}$ Edition. Plymouth: MacDonald Evans Limited.

Hall, D., and Nougaim, K. (2000). An Examination of Maslow Need Hierarchy in an Organisational Setting.

Herzberg, F. (1959). The Motivation to Work, New York, John Wiley and Sons.

Jakobson, L. (2007). Harrah’s Teams Up, Business. Premier Database, January.

Kellerman, B. (2007). What Every Leader Needs to Know About Followers. Business Source Premier Database.

Kunda, Z. (1990). The Case for Motivated Reasoning. Psychological Bulletin.

Laurie, J. M. (1996). Management and Organisational Behaviour. $4^{\text {th }}$ Edition Pitman Publishers Washington DC.

Maslow, A. (1954). Motivation and Personality. Harper and Row New York, New York, 1954

McGregor, D. (1960). The Human Side of Enterprise. McGraw Hill Professional.

Mckenzie, R., and Lee, D. (1998). Managing through Incentives. Oxford University Press.

Olajide, A. (2000). Getting the Best out of Employees in a Developing Economy. University of Ibadan, Nigeria.

ORBRDA Annual Report (June I98I).

ORBRDA 1986 Annual Report p. I (June I987).

Quattron, G. A. (1985). On the Congruity between Internal States and Action. Psychological Bulletin

River Basin Development Authorities Decree (No. 87) p. A683 (I979).

River Basin Development Authorities Decrees (p. 688) (1979).

Simms, J. (2007). Beyond the Fringe, Business Source Premier Database.

Stephanie (2018). Chi Square Statistics in Research. Retrieved from: http://www.statisticssolutions.com/using-ChiSquarestatistics-in- research/ 
Szilagyi, A. D., and Marc, J. W., JR., (1987). Organisational Behaviour and Performance. $4^{\text {th }}$ Edition, London Scott, Foresman and Company.

Taylor, F. W. (I9I I). Principles of Science Management. Routledge.

Whiteling, I. (2007). A Message from the Frontline. Business Source Premier Database.

\section{Copyrights}

Copyright for this article is retained by the author(s), with first publication rights granted to the journal. This is an open-access article distributed under the terms and conditions of the Creative Commons Attribution license (http://creativecommons.org/licenses/by/4.0/). 